\title{
IMPROVING SPEAKING SKILL THROUGH NUMBERED HEADS TOGETHER OF THE SEVENTH GRADE STUDENTS OF SMP PGRI 4 DENPASAR IN ACADEMIC YEAR 2014/2015
}

\author{
Eva Shinta Dewi, Ni Wayan Krismayani, Ni Made Wersi Murtini \\ English Education Study Program, Faculty of Teacher Training and Education, \\ Mahasaraswati Denpasar University.
}

\begin{abstract}
This study was intended to figure out the effectiveness of Numbered Heads Together in improving speaking skill of the seventh grade students of SMP PGRI 4 Denpasar. This study was conducted in class VII B which consisted of 16 students: 12 males and 4 females. This study was conducted by the fact that the subjects still faced problem in speaking skill especially in vocabulary, pronunciation, and grammar. Based on the result of the pre-test which was carried out in the pre-cycle, among 16 subjects who did the pre-test, there was none of the subjects passed the minimum score. The present study was then carried out by implementing Numbered Heads Together in successive two cycles where each cycle consisted of two sessions. The results of post-tests score for cycle I was 2.67 while in cycle II was 3.18 . The results of post-test in each cycle showed that there was a significant progressing achievement of the subjects' speaking skill. In addition, the data analysis of questionnaire score showed the comparative percentages figures of $55.78 \%$ for option A, $42.40 \%$ for option B, $1.80 \%$ for option C and $0 \%$ of option D. The result of the questionnaire above clearly showed that the students' learning behavior and motivation have been improved significantly when Numbered Heads Together was implemented in teaching speaking. In conclusion, the present classroom action study proved that Numbered Heads Together was effective to improve the seventh grade students' of SMP PGRI 4 Denpasar ability in speaking skill; in addition, the subjects also responded positively to the implementation of Numbered Heads Together.
\end{abstract}

Keywords: Speaking, Numbered Heads Together.

\begin{abstract}
ABSTRAK
Penelitian ini bertujuan untuk mengetahui pengaruh Numbered Head Together dalam meningkatkan kemampuan berbicara siswa kelas tujuh SMP PGRI 4 Denpasar. Penelitian ini dilaksanakan di kelas VIIB yang terdiri dari 16 siswa, 12 laki-laki dan 4 perempuan. Dilaksanakannya penelitian ini berangkat dari fakta bahwa siswa mengalami permasalahan dalam berbicara bahasa Inggris khususnya dalam hal kosa kata, pengucapan, dan tata bahasa. Berdasarkan hasil pre-test yang dilaksanakan saat siklus awal, dari 16 siswa tidak ada satu pun yang berhasil melewati skor minimum. Penelitian ini kemudian dilakukan dengan menerapkan tehnik Numbered Head Together dalam dua siklus dimana masing-masing siklus terdiri dari dua sesi. Hasil dari nilai post-test untuk siklus 1 adalah 2.67 dan pada siklus dua menjadi 3.18. Hasil
\end{abstract}


post-test dari masing-masing siklus menunjukkan bahwa ada peningkatkan pencapaian yang signifikan dari kemampuan berbicara siswa. Demikian pula dari hasil data analisis kuisioner menunjukkan angka persentase $55.78 \%$ untuk pilihan A, $42.40 \%$ untuk opsi B, 1.80\% untuk pilihan $\mathrm{C}$ and $0 \%$ untuk pilihan D. hasil kuisioner tersebut menunjukkan bahwa terdapat perubahan sikap belajar dan motivasi siswa pun meningkat secara signifikan ketika tehnik Numbered Head Together diterapkan dalam mengajar berbicara (speaking). Kesimpulannya, Numbered Head Together dengan effektif mampu meningkatkan kemamuan berbicara siswa kelas tujuh B SMP PGRI 4 Denpasar, dan juga subjek merespon dengan positif penerapan Numbered Head Together.

Kata Kunci: Speaking, Numbered Heads Together

\section{INTRODUCTION}

One of the language skills that must be mastered by any foreign language learners is the ability to speak or communicate in the target language fluently. In language learning, speaking skill is one of productive skills which aims to enable people to communicate effectively in spoken English as the objective of teaching English as a foreign language. Hybel (2001:45) states that speaking is a process of sharing information, feeling, and ideas; it involves all of body language mannerism and style-anything that adds meaning to a message. Luoma (2004) argues that speaking takes a long time to develop. To speak in a foreign language learners we must master the sound system of the language, have almost instant access to appropriate vocabulary and be able to put words together intelligibly with minimal hesitation. In the speaking class, mostly the students faced some problems in sound, grammar, and structure of target language which is quite different from their native language. We often find the students hardly use English for communication even in the simple form or we may find the students who are able to point the answer of the question on the text but they cannot explain their reason in choosing the answer.

Speaking requires not only knowing how to produce specific points of language such as grammar, vocabulary, sound, pronunciation, intonation, stress, lexical, and semantic features which is known as linguistic competence one of which including nonverbal communication 
such as eye contact, gesture, and facial expression. It is also evident that in class the students have limited time to practice their speaking skills, and it resulted on their ability to use the target language. As we know, the problems that may prohibit the students to develop their speaking skill, which are inhibition low participation and students prefer to use their native language. Other related problem of English speaking students is the method of teaching learning that is used by the teacher. Most of methods used sometimes make the students easily getting bored and sometimes those methods force them too hard to speak up, therefore, they do not enjoy teaching and learning process. The situation above is not good atmosphere for learning language.

Based on the observation conducted in SMP PGRI 4 Denpasar, there are many problems encountered by the students in learning speaking. First, the students do not have a good motivation in learning. It can be seen that the students still feel reluctant to speak in front of the class. They still feel shy to express their ideas in English. Second, the students are usually lazy to speak or do conversation using English. They are often not confident with themselves. Third, the teacher is dominantly using Indonesian language. Fourth, the students have lack of vocabulary, pronunciation, and grammar.

Based on the problems above, it showed that in order to be successful in teaching speaking, the teacher must know the best technique or strategy that can be applied in teaching speaking skill. The strategy should be attractive, interactive, and innovative. The teacher must know the strengths and weaknesses of the strategy before applying it in the class. The teacher must be sure that the strategy is able to make students feel confident to speak up.

One of the strategies that the researchers choose to improve the speaking skill of students is Numbered Heads Together. Numbered Heads Together is a cooperative strategy that offers an alternative to the competitive approach and then calls on one of the students with a raised hand. It is considered as the best strategy because it was a type of cooperative method where the students can learn in groups. Learning in groups brings many 
advantages for students. One of them is to share to each other. This structure facilitates positive independence, while promoting individual accountability. The students can work collaboratively with their friends. It also gives confidence to the lower achievers.

Therefore, in accordance with the above facts, the researchers are highly motivated to investigate the effectiveness of Numbered Heads Together in improving the speaking skill of the first grade students of SMP PGRI 4 Denpasar in academic year $2014 / 2015$.

\section{RESEARCH DESIGN}

This study focused on improving speaking through Numbered Heads Together. It made use of Classroom Action Research (CAR) design, to solve the problem of the students in the classroom while the learning and teaching process. The subjects of this classroom action study were the seventh grade students of SMP PGRI 4 Denpasar. There were 2 classes of the seventh grade students of SMP PGRI 4 Denpasar. In this study, the researchers chose class VII B as the subjects of the study which consisted of 16 students. There were
12 males and 4 females students in this class. In this classroom action study, the teaching learning process was divided into two cycles and each cycle consisted of planning, action, observation and reflection. In collecting the data, there are several instruments used such as: pre-test, post-test and questionnaire. Then, the data required to answer the research question was gathered through administering pre-test before the researchers began the teaching learning process and post-test was given at the end of each cycle, and questionnaire was given at the end of cycle II.

\section{FINDINGS AND DISCUSSION}

As mentioned in previous chapter, this study was designed as classroom action research. The present study was intended to figure out the effectiveness of Numbered Heads Together in teaching speaking.

In pre-test, the subjects were assigned to do a dialogue presentation after selecting one of the topics given. The result of pre-test was not satisfying. There were two students who got the lowest score, 44 and 45 . The lowest aspect obtained by the students was grammar. In addition, 
based on the result above, the researchers subsequently started to conduct cycle I.

In post-test I, there were still several students who got low score but the score was better than the pre-test score. This meant that Numbered Heads Together could improve the subjects' speaking ability. There were 5 or equivalent to $31.25 \%$ subjects successfully obtained minimum passing grade 75. However, the success indicator had not been achieved yet in the first cycle. Then, in post-test 2 , there were 14 or equivalent to $87.5 \%$ of the subjects successfully obtained minimum standard passing grade. Therefore, the result of the last post-test showed this research also had achieved the success indicator. As the result, the research could be ended.

In the end of cycle II, the researchers also administered questionnaire to the subjects under the study. The result of the questionnaire also showed that there were $55.78 \%$ of subjects who liked very much and appreciated the technique applied by the researchers, $42.40 \%$ of them liked the technique, $2.15 \%$ of them did not really enjoy the technique and $0 \%$ of them did not like the technique at all when the teacher applied Numbered Heads Together technique in their speaking class. The result of the questionnaire above clearly showed that the students' learning behavior and motivation have been improved significantly when Numbered Heads Together was implemented in teaching speaking.

\section{CONCLUSIONS}

The present classroom action study was conducted to help the students improve and develop their ability in speaking skill. The data obtained from this study which were in form of score that showed the students' progress in speaking skill were descriptively analyzed in which the means score obtained from the subjects in pre-test scores were compared with their corresponding means scores in the post-test.

The result of the questionnaire analysis scores clearly showed the comparative percentages figures $55.78 \%, 42.40 \%, 1.80 \%$ and $0 \%$ for receptive total responses of the items of the questionnaire option $\mathrm{A}, \mathrm{B}, \mathrm{C}$, and D. These findings significantly proved that the learning motivation of the subjects under study changed and heightened positively. In conclusion, 
improving speaking skill through

Numbered Heads Together could make the students active in learning and significantly improve their speaking skill.

\section{REFERENCES}

Arends, R.I. 2007. Learning to Teach Seventh Edition. New York: McGraw Hill.

Brown, H. D. 2004. Language Assessement Principles and Classroom Practices. Pearson Education: Longman.

Burns, A., and Claire, S. 2003. Clearly Speaking Pronunciation in Action for Teacher. Sydney: AMEP Research Centre.

Freeman, D. L. 2000. Technique and Principles in Language teaching. Second Edition. New York: Oxford University Press.

Hiebert, E.H., and Kamil, M.L. (Eds.) 2005. Teaching and learning vocabulary: Bringing research to practice. Mahwah, NJ: Lawrence Erlbaum Associates.

Hybel, R. L. 2001. Communicating Effectively. New York: Mc. Grow-Hill Higher Education.

Jolliffe, W. 2007. Cooperative Learning in the Classroom. London: Paul Chapman Publishing.

Kagan, D. S. 2009. Kagan Cooperative Learning. Kagan Publishing.

Louma, S. 2004. Assessing Speaking: Cambridge language assessment Series. UK: Cambridge University Press.

Nunan, D. 2005. Important Task of English Education: Asian- wide and beyond. Asian EFL Journal Vol.7.Issue 3.

Richards, J. C. 2008. Teaching Listening and Speaking. (First Edition). Cambridge. Cambridge University Press.

Thornbury, S. 2005. How to Teach Speaking. Pearson Education ESL: Longman.

Tileston, D. W. 2004. What Every Teacher Should Know About Effective Teaching Strategies. California: Corwinn Press. 